\title{
ISOTOPES, INC. RADIOCARBON MEASUREMENTS I
}

\author{
ALAN WALTON, MLLTON A. TRAUTMAN and JAMES P. FRIEND
}

\author{
Isotopes, Incorporated, Westwood, New Jersey
}

INTRODUCTION

Radiocarbon analyses have been performed at Isotopes, Inc. since 1957 using proportional-counting techniques. Carbon dioxide is employed as the counting gas at pressures up to two atmospheres. The counter presently in service is electrolytic copper and has an active volume of just under two liters. It is shielded by one in. of mercury, a ring of 23 G-M counters operated in anti-coincidence with the sample counter, $4 \mathrm{in}$. of paraffin wax, and $18 \mathrm{in}$. of hot-rolled steel. A background of 9.2 counts $/ \mathrm{min}$ has been attained with this arrangement.

Prior to use of the NBS oxalic-acid standard, our modern standard was 1885 pine wood. Age corrected to 1960 , this wood had an activity of $94.0 \pm$ $1.9 \%$ of the NBS oxalic-acid standard. We are now using the NBS oxalic-acid standard as our modern value and $\mathrm{A}_{\mathrm{ox}} \times 0.95$ is 23.3 counts $/ \mathrm{min}$ corrected to a standard temperature of $273^{\circ} \mathrm{K}$. Shell dates reported below were calculated using the pine-wood standard, without correction for supposed fractionation of carbon isotopes.

Sample pretreatment consists of removal of rootlets and gross contaminants, leaching with $1 \%$ hot $\mathrm{HCl}$ or $\mathrm{H}_{3} \mathrm{PO}_{4}$ in all cases, and with hot $1 \%$ $\mathrm{NaOH}$ in those cases where humics are likely to be present. Final washings in distilled water are always given. Shells are scrubbed and leached to remove outer layers. Samples are then either burned or hydrolyzed and $\mathrm{CO}_{2}$ evolved is purified according to standard procedures. Radon is removed during purification, and as a final check the radon content of the $\mathrm{CO}_{2}$ is monitored by counting on the alpha plateau.

Samples with code numbers I (GSC) - 1 through 12, I (OSU) -80, I (MI) -9 and 27, I (USG) - 34 , I (UW) - 79 , I ( AMNH) $-39,41,43,44,47$ and 48 , and $\mathrm{I}(\mathrm{RB})-46$ were counted in a small counter of ca. $400 \mathrm{cc}$ volume which is no longer in routine use. Counting and preparation procedures were similar to those now followed. The small counter had a background of 2 counts $/ \mathrm{min}$ and a modern-standard activity of 3.5 counts $/ \mathrm{min}$.

Each sample is counted at least twice for 8 to 15 hours, several days apart. Errors quoted include uncertainties associated with the unknown, modern, and hackground-sample determinations. Also included is the error in the $\mathrm{C}^{14}$ halflife (5568 \pm 30 years), but no account has been taken of the deVries effect (deVries, 1958).

\section{ACKNOWLEDGMENTS}

Data obtained at Isotopes, Inc. are the sole property of our clients, and up to now only a small number of results has appeared in print. However, during the past year we have endeavored to encourage our clients to submit full descriptions of their samples and these dates are published with their con- 
sent. We wish to express, therefore, our deep gratitude for the descriptions, comments and continued cooperation of all those mentioned in the following date list. In addition, we are indebted to Shirley A. Rickert of Isotopes, Inc. for her excellent assistance in the laboratory work.

\section{SAMPLE DESCRIPTIONS}

\section{GEOLOGIC SAMPLES}

The following series of samples, from many areas in Canada, was coll. by the staff of Geol. Survey of Canada and subm. over a period of $2.5 \mathrm{yr}$ by Dept. of Mines and Technical Surveys, Geol. Survey of Canada, Ottawa, Ontario, Canada.

\section{A. Western Canada}

I(GSC)-1. Parksville, Vancouver Island

$12,000 \pm 450$

Wood excavated from E bank of Englishman River, Vancouver Island, ca. $3 \mathrm{mi}$ SE of Parksville ( $49^{\circ} 17^{\prime} \mathrm{N}$ Lat, $124^{\circ} 12^{\prime} \mathrm{W}$ Long). Sample coll. ca. $60 \mathrm{ft}$ below top of bank, $100 \mathrm{ft}$ high, from bottomset sands of a marine delta with top surface $170 \mathrm{ft}$ above present sealevel. Coll. 1956 by J. G. Fyles; subm. 1958. Comment: highest and earliest postglacial-marine level is at alt $470 \mathrm{ft}$. Above date relates to a younger level (Terasmae and Fyles, 1959). Sample is also a duplicate of L-391 D, 12,150 \pm 250 (Lamont V).

I (GSC)-5. Oyster River, Vancouver Island

Wood taken from SE bank (80 ft high) of Oyster River, Vancouver Island ( $49^{\circ} 53^{\prime} \mathrm{N}$ Lat, $125^{\circ} 11^{\prime} \mathrm{W}$ Long). Wood was dug from a 17 -ft layer of silt, sand, and gravel ca. $35 \mathrm{ft}$ below top of bank. Layer is underlain by till and overlain by two lithologically-distinct tills, as well as by postglacial marineand deltaic deposits. Coll. 1957 by J. G. Fyles; subm. 1958. Comment: woodbearing sediments such as these have been found in several places in Oyster River area of Vancouver Island and have yielded coniferous pollen recording a climate cooler than the present. Relation of these deposits to the more widespread Quadra sediments is not known.

I(GSC)-9. Courtenay, Vancouver Island gravel pit $12,500 \pm 450$

Marine pelecypod shells from Marriots gravel pit. Cumberland Road, between Courtenay and Cumberland, Vancouver Island $\left(49^{\circ} 38^{\prime} 40^{\prime \prime} \mathrm{N}\right.$ Lat, $125^{\circ}$ $00^{\prime} 20^{\prime \prime} \mathrm{W}$ Long). Shells coll. in floor of pit from stony clay which lies beneath thick gravels forming the front of an ice-contact delta with upper surface (alt ca. $500 \mathrm{ft}$ ) at highest marine level in vicinity. Coll. 1956 and 1957 by J. G. Fyles; subm. 1958. Comment: shell-bearing clay apparently accumulated at ca. same time as delta, shortly after deglaciation permitted influx of sea into this part of the Georgia depression. Sample was exceedingly small and collection site only fair, hence date is only approximate.

I(GSC)-10. Courtenay, Vancouver Island, kettle $\quad 11,780 \pm 450$

Peat sample from bog in kettle, $100 \mathrm{yd}$ SW of Courtenay Sand and Gravel Co. pit, on Cumberland Road between Courtenay and Cumberland $\left(49^{\circ} 38^{\prime}\right.$ $30^{\prime \prime} \mathrm{N}$ Lat, $125^{\circ} 00^{\prime} 10^{\prime \prime} \mathrm{W}$ Long). Dated material consists of basal peat from 
two cores, taken $5 \mathrm{ft}$ apart, at a depth of 6.4 to $6.5 \mathrm{~m}$ from kettle in marine ice-contact delta. Top surface alt is $500 \mathrm{ft}$. Coll. 1957 by J. G. Fyles; subm. 1958. Comment: delta is one of earliest marine deposits built at highest stand of sealevel by a river flowing off glacier ice during deglaciation. Date gives a minimum age for this delta (see I (GSC) -9).

I(GSC)-6. Lower Fraser Valley, British Columbia 12,625 \pm 450

Marine pelecypods coll. from drainage ditch on $\mathrm{E}$ side of King George Highway, Sunnyside, near Whiterock, British Columbia $\left(\sim 49^{\circ} 01^{\prime} \mathrm{N}\right.$ Lat, $122^{\circ} 50^{\prime}$ WLong). Shells inclosed in stony clay beneath ca. $5 \mathrm{ft}$ of marine sand at alt ca. $260 \mathrm{ft}$. Coll. 1957 by J. E. Armstrong; subm. 1958.

\section{B. Eastern Canada}

I (GSC)-11. Hamilton, Ontario

$10,150 \pm 450$

Plant material from 203 to $204.5 \mathrm{ft}$ below present level of Lake Ontario, beneath Burlington Bar, Hamilton, Ontario ( $43^{\circ} 18^{\prime} \mathrm{N}$ Lat, $79^{\circ} 48^{\prime} \mathrm{W}$ Long). Sample taken from boring \#F-1-36 (Ontario Hydroelectric Power Commission $)$. Material lay near base of thick succession $(\sim 200 \mathrm{ft})$ of lake sediments lying upon glacial deposits. Coll. 1958 by Ontario Hydroelectric Power Commission for J. Terasmae; subm. 1958. Comment: date applies to an early stage of Lake Ontario when water level of $\mathrm{W}$ end of lake appears to have been lower than at present. Younger and higher samples from these deposits have been dated at $5240 \pm 140(\mathrm{Y}-614 \mathrm{~A})$ and $2830 \pm 160(\mathrm{Y}-613 \mathrm{~A} ;$ Yale V).

I (GSC)-14. Missinaibi River, Ontario

$7875 \pm \mathbf{2 0 0}$

Marine pelecypod shells from top of $\mathrm{N}$ bank of Missinaibi River, $13.5 \mathrm{mi}$ downstream from Bulls Bay $\left(50^{\circ} 13^{\prime} \mathrm{N}\right.$ Lat, $82^{\circ} 54^{\prime} \mathrm{W}$ Long). Collection site is $115 \mathrm{ft}$ above river, alt ca. $400 \mathrm{ft}$; shells from $3.5 \mathrm{ft}$ of wavy-bedded silt and sand that rests upon laminated clay. Coll. 1954 by O. S. Hughes; subm. 1959. Comment: dated shells are believed to have formed during the earliest, highest stand of sea, $\mathrm{S}$ of James Bay, immediately following deglaciation of the locality (Terasmae and Hughes, 1960; Lee, 1960).

I(GSC)-29. Galt, Ontario

$11,950 \pm 350$

Peat and gyttja from basal organic sediment at depth 295 to $305 \mathrm{~cm}$, in Grieff Kettle Bog, $8 \mathrm{mi}$ NE of Galt, Ontario (43 $25^{\prime} \mathrm{N}$ Lat, $80^{\circ} 11^{\prime} \mathrm{W}$ Long). Coll. 1959 by J. Terasmae; subm. 1959. Comment: dated material was formed at initial stage of bog development in a kettle on Galt Moraine. The date, therefore, provides a minimum age for deglaciation of the moraine.

I (GSC)-3. Little Current, Manitoulin Island

$9450 \pm 300$

Peat taken from base of organic bog sediment, 188 to $198 \mathrm{~cm}$ below bog surface, alt ca. $1000 \mathrm{ft}$, SW of Little Current, Manitoulin Island $\left(45^{\circ} 56^{\prime} \mathrm{N}\right.$ Lat, $82^{\circ} 00^{\prime} 30^{\prime \prime} \mathrm{W}$ Long) . Coll. 1957 by J. Terasmae; subm. 1958. Comment: sample site is above highest level of glacial Great Lakes; date indicates minimum time elapsed since area was deglaciated (Terasmae and Hughes, 1960).

I(GSC)-15. Guyer Lake, Quebec $\quad \mathbf{5 4 7 5} \pm \mathbf{1 6 0}$

Peat from depth of 4.2 to $4.4 \mathrm{ft}$ below surface in bog near Guyer Lake, 
Quebec ( $53^{\circ} 35^{\prime} \mathrm{N}$ Lat, $74^{\circ} 41^{\prime}$ W Long). Coll. 1957 by H. A. Lee; subm. 1959. Comment: sample site is above limit of marine submergence; dated peat marks beginning of postglacial-bog development at site. Age indicates minimum time elapsed since deglaciation (Lee, Eade, and Heywood, 1960).

\section{I (GSC)-12. Iris Station, Prince Edward Island}

$6600 \pm 270$

Peat dug from base of roadside $0.5 \mathrm{mi} \mathrm{E}$ and $1 \mathrm{mi} \mathrm{S}$ of Iris railroad sta. tion, Prince Edward Island ( $45^{\circ} 59^{\prime} \mathrm{N}$ Lat, $62^{\circ} 42^{\prime} 30^{\prime \prime} \mathrm{W}$ Long). Sample from depth of $5 \mathrm{ft}$ at base of peat resting upon till. Coll. 1956 by L. Frankel; subm. 1958. Comment: palynological work by J. Terasmae indicates dated material accumulated during an early phase of postglacial-thermal maximum.

\section{I (GSC)-23. Nicholas Point, Prince Edward Island $915 \pm 90$}

Wood from one of several tree stumps rooted in peat on intertidal part of beach at Nicholas Point, $8 \mathrm{mi}$ W of Wood Island on the SE coast of Prince Edward Island ( $45^{\circ} 59^{\prime} 30^{\prime \prime} \mathrm{N}$ Lat, $62^{\circ} 52^{\prime} 30^{\prime \prime} \mathrm{W}$ Long). Dated sample taken from tree rooted $5.4 \mathrm{ft}$ below high tide level. Tree and peat rest upon marine deposits. Coll. 1957 by L. Frankel; subm. 1959. Comment: date indicates time of drowning of forest and peat hog and provides data on rate of submergence of this region. Submergence is believed to be still in progress.

\section{I (GSC)-2. Green River, New Brunswick $\quad 10,220 \pm 350$}

Peat coll. from basal 0.5 in. of a 1.4-ft thick bog layer which lies beneath clay and rests upon gravel on $\mathrm{E}$ hank of Green River ca. $2 \mathrm{mi} \mathrm{N}$ of its confluence with Saint John River $\left(47^{\circ} 19^{\prime} \mathrm{N}\right.$ Lat, $68^{\circ} 07^{\prime} \mathrm{W}$ Long). Coll. 1956 by H. A. Lee; subm. 1958. Comment: date indicates minimum age of the Grand Falls drift and disappearance of glacial ice from this part of New Brunswick (Lee, 1959h).

\section{I (GSC) -7. Saint John, New Brunswick}

$13,325 \pm \mathbf{5 0 0}$

Marine molluscan shells collected from clay exposed on sea cliff at Smugglers, about $5 \mathrm{mi}$ W of Saint John, New Brunswick $145^{\circ} 13^{\prime} \mathrm{N}$ Lat. $66^{\circ}$ $07^{\prime}$ W Long). Clay lies beneath and intertongues with delta-outwash gravels. Coll. 1958 by H. A. Lee; subm. 1958. Comment: dated shells were formed during, or shortly after retreat of glacial margin from the vicinity.

\section{I (GSC) -4. Whitbourne, Avalon Peninsula $\quad \mathbf{8 4 2 0} \pm \mathbf{3 0 0}$}

Peat-gyttja taken at a depth of 4.85 to $5.00 \mathrm{~m}$ in transition zone from overlying peat to silt in a bog located at $\mathrm{N}$ end of Whithourne, Avalon Peninsula, Newfoundland (47 $25^{\prime} 30^{\prime \prime} \mathrm{N}$ Lat, $53^{\circ} 32^{\prime} \mathrm{W}$ Long). Coll. 1958 by E. P. Henderson; subm. 1958. Comment: date indicates minimum time elapsed since area was uncovered by last ice sheet.

\section{Northern Canada}

\section{I (GSC) -8. Keewatin, NW Territories}

$6975 \pm 250$

Marine pelecypod shells from clay exposed on river bank $1 \mathrm{mi} \mathrm{S}$ of Carr Lake $\left(62^{\circ} 10^{\prime} \mathrm{N}\right.$ Lat, $95^{\circ} 4 \mathrm{l}^{\prime} \mathrm{W}$ Long), alt $210 \mathrm{ft}$. Coll. 1952 by H. A. Lee; subm. 1958. Comment: shells coll. at hase of hill that extended above marine 
limit ( $560 \mathrm{ft}$ above present sealevel). Date believed to represent time of maximum stand of Tyrell Sea (Lee, 1959a, 1960; Craig and Fyles, 1960).

\section{I(GSC)-13. Port Epworth, Coronation Gulf, NW Territories}

$8290 \pm 330$

Marine pelecypod shells from "mud-gravel of dolomite hills of $\mathrm{S}$ end of Port Epworth, Coronation Gulf, (Canadian Arctic Expedition-1924) alt 320 ft" (67 $47^{\prime}$ N Lat, $110^{\circ} 55^{\prime} \mathrm{W}$ Long). Coll. 1916 by J. J. O'Neill; subm. 1959. Comment: dated shells represent a sealevel $320 \mathrm{ft}$ or more above present position and $300 \mathrm{ft}$ or less below limit of marine submergence in vicinity. Date applies to middle of interval of rapid uplift of land that followed retreat of Laurentide ice sheet (Craig and Fyles, 1960; Craig, 1960) (cf. samples I (GSC) 16, 17, 22 and 25).

\section{I (GSC) -16. Kugaryuak River, Coronation Gulf, NW Territories} from gullied surface of marine clay $\left(67^{\circ} 39^{\prime} \mathrm{N}\right.$ Lat, $113^{\circ} 19^{\prime} \mathrm{W}$ Long). Coll. 1959 by B. G. Craig; subm. 1959. Comment: shells coll. close to upper limit of marine submergence; date from early part of interval of marine submergence that followed retreat of Laurentide ice sheet (Craig and Fyles, 1960; Craig, 1960) (cf. samples I (GSC) - 13, 17, 22 and 25).

\section{I(GSC)-17. Tree River, Coronation Gulf, NW Territories}

$10,215 \pm 220$

Marine pelecypod shells embedded in erosional remnants of marine clay, coll. in valley of Tree River, S of Coronation Gulf $\left(67^{\circ} 30^{\prime} 15^{\prime \prime} \mathrm{N}\right.$ Lat, $112^{\circ}$ $02^{\prime}$ W Long), alt 282 ft. Coll. 1959 by B. G. Craig; subm. 1959. Comment: date from shells represents a time soon after retreat of Laurentide ice sheet from site when the sealevel was $300 \mathrm{ft}$ or more above its present position and $300 \mathrm{ft}$ or less below its maximum stand. (See samples I (GSC)-13, 16, 22 and 25 and Craig and Fyles, 1960; Craig, 1960).

\section{I (GSC)-22. Asiak River, Coronation Gulf, NW Territories}

Marine pelecypod shells from fine sand, alt ca. $425 \mathrm{ft}$, on outer face of an esker delta ca. $28 \mathrm{mi} \mathrm{SE}$ of Coppermine $\left(67^{\circ} 41^{\prime} \mathrm{N}\right.$ Lat, $114^{\circ} 27^{\prime} \mathrm{W}$ Long). Top surface alt of delta ca. $450 \mathrm{ft}$. Coll. 1959 by R. J. Fulton for B. G. Craig; subm. 1959. Comment: upper limit of marine submergence in vicinity is ca. $500 \mathrm{ft}$ alt. Dated shells are inferred to have originated close to front of retreating Laurentide Ice Sheet or shortly after its retreat (cf. I (GSC)-13, 16, 17 and 25 ). Younger age of this sample was unexpected and older dates probably provide a more reliable indication of time of glacial retreat. (Craig and Fyles, 19601.

\section{I (GSC)-25. Harding River, Dolphin and Union Strait, NW \\ Territories $\quad 10,530 \pm 260$}

Marine pelecypod shells coll. at alt ca. $244 \mathrm{ft}$ in very fine sand, $\mathrm{S}$ of Dolphin and Union Strait, near Harding River $\left(68^{\circ} 47^{\prime} \mathrm{N}\right.$ Lat, $116^{\circ} 56^{\prime} \mathrm{W}$ 
Long). Coll. 1959 by B. G. Craig; subm. 1959. Comment: date represents a time soon after retreat of Laurentide ice sheet from site when the sealevel was within $100 \mathrm{ft}$ of its earliest and highest stand (Craig and Fyles, 1960). (cf. samples I(GSC) -13, 16, 17 and 22).

\section{I(GSC)-18. Peel Point, Victoria Island, NW Territories}

$$
12,400 \pm 320
$$

Shells of Yoldia arctica (id. by F. J. E. Wagner, Geol. Survey of Canada) from $5 \mathrm{mi} \mathrm{S}$ of Peel Point at the NW extremity of Victoria Island, alt $220 \mathrm{ft}$ ( $73^{\circ} 18^{\prime} \mathrm{N}$ Lat, $114^{\circ} 30^{\prime} \mathrm{W}$ Long). Shells inclosed in clay which rests upon stratified silt and sand. Coll. 1959 by J. G. Fyles; subm. 1959. Comment: dated shells occur within $50 \mathrm{ft}$ of limit of marine submergence; are believed to have originated during deglaciation, in a narrow body of sea water bordering the glacial ice in Prince of Wales Strait and Viscount Melville Sound (Craig and Fyles, 1960).

\section{I(GSC)-19. Banks Island, NW Territories (in silt)}

Wood coll. half way up a $100-\mathrm{ft}$ cliff on W coast of Banks Island at Worth Point $\left(72^{\circ} 15^{\prime} \mathrm{N}\right.$ Lat, $125^{\circ} 40^{\prime} \mathrm{W}$ Long). Dated wood is representative of small trees and beaver-gnawed sticks, apparently embedded in pond silts resting upon till, which in turn overlies Beaufort formation. A younger till (?) may separate wood-bearing silts from uncompressed surface peat (see (I-GSC) 26). Coll. 1959 by J. G. Fyles; subm. 1959. Comment: (see I (GSC)-28) .

\section{I (GSC)-26. Banks Island, NW Territories (in uncompressed peat)}

$>\mathbf{3 8 , 0 0 0}$

Wood (dwarf willow) from same site as I (GSC) - $19\left(72^{\circ} 15^{\prime} \mathrm{N}\right.$ Lat, $125^{\circ}$ $40^{\prime}$ W Long). Sample coll. from 6 -ft bed of uncompressed moss peat at top of the exposure. Peat has yielded pollen of birch, in addition to that of plants now growing in the area. Coll. 1959 by J. G. Fyles; subm. 1959. Comment: uncompressed surface peat containing dated wood has accumulated since last glaciation of $\mathbb{W}$ part of Banks Island. This radiocarbon age supports the inference (based upon other features of the region) that W Banks Island was not glaciated during "classical" Wisconsin time.

\section{I (GSC) -28. Bernard Island, near Banks Island, NW Territories}

$>38,000$

Moss peat from shore cliff at SW end of Bernard Island which lies off the mouth of Bernard River on W coast of Banks Island $\left(73^{\circ} 40^{\prime} \mathrm{N}\right.$ Lat, $124^{\circ} 25^{\prime}$ W Long). Moss peat occurs in lacustrine silts lying beneath till or colluvium and overlying till which in turn rests upon Beaufort formation. Pollen of conifers and tundra vegetation now found in area has been obtained from the moss. Coll. 1959 by J. G. Fyles; subm. 1959. Comment: lacustrine or pond silts containing dated moss and other similar deposits on $\mathrm{W}$ Banks Island (see I(GSC)-19), appear to record a sparsely forested interglacial period (Craig and Fyles, 1960). 


\section{I (GSC)-20. Holman Island, Victoria Island, NW Territories}

$8895 \pm 220$

Marine pelecypod shells from wet clay on left bank of small river $0.25 \mathrm{mi}$. from its mouth and $1 \mathrm{mi} \mathrm{NE}$ of Holman Island Post, Victoria Island $\left(70^{\circ} 44^{\prime}\right.$ $\mathrm{N}$ Lat, $117^{\circ} 46^{\prime} \mathrm{W}$ Long). Shells coll. ca. $25 \mathrm{ft}$ above present sealevel from unoxidized fetid clay that appears to be bottomset part of small delta formed when the seashore stood about $30 \mathrm{ft}$ above its present level. Coll. 1959 by J. G. Fyles; subm. 1959. Comment: limit of marine submergence in W Victoria Island is ca. $300 \mathrm{ft}$ above present sealevel. In view of this date, most of this $300-\mathrm{ft}$ uplift of the land relative to the sea occurred more than $9,000 \mathrm{yr}$ ago (Craig and Fyles, 1960).

\section{I (GSC) -30. Prince Albert Sound, Victoria Island, NW Territories \\ $\mathbf{2 8 , 0 0 0} \pm \mathbf{1 5 0 0}$}

Tundra plants dug from $200-\mathrm{ft}$ river bank ca. $5 \mathrm{mi} \mathrm{N}$ of Prince Albert Sound on Victoria Island $\left(70^{\circ} 38^{\prime} \mathrm{N}\right.$ Lat, $116^{\circ} 35^{\prime} \mathrm{W}$ Long). Organic material occurs as a succession of thin-growth layers in a $20-\mathrm{ft}$ section of silt, lying within ca. $150 \mathrm{ft}$ of gravel and sand. These stratified deposits underlie till and glacial gravel and overlie till. Pollen derived from organic layers belongs entirely to tundra plants. Coll. 1959 by J. G. Fyles; subm. 1960. Comment: dated material is believed to record an interstadial interval. Deposits inclosing dated material are of local extent, but may correlate with similar materials (which so far have yielded no organic remains) that lie beneath till throughout large parts of NW Victoria Island and NE coast of Banks Island.

I (GSC)-21. Melville Island, NW Territories $\quad \mathbf{8 2 7 5} \pm \mathbf{3 2 0}$

Marine pelecypod shells coll. ca. $175 \mathrm{ft}$ above sealevel near Tingmisut Lake on Melville Island ( $75^{\circ} 50^{\prime} \mathrm{N}$ Lat, $108^{\circ} 00^{\prime} \mathrm{W}$ Long). Limit of marine submergence is ca. $270 \mathrm{ft}$ above present sealevel. Coll. 1959 by E. T. Tozer for J. G. Fyles; subm. 1959. Comment: NW peninsula of Melville Island as yet has yielded no evidence of glaciation. This date indicates, however, uplift of land relative to sea during "normal" postglacial interval as if through isostatic rebound following the retreat of Wisconsin-age glaciers (Craig and Fyles, 1960).

I (GSC) -24. Lougheed Island, NW Territories $\quad 8200 \pm 180$

Marine pelecypod shells from 75 to $100 \mathrm{ft}$ above sealevel, 2.5 to $3 \mathrm{mi}$ inland from NE coast of Lougheed Island $\left(\sim 77^{\circ} 33^{\prime} \mathrm{N}\right.$ Lat, $105^{\circ} \mathrm{W}$ Long $)$. Marine shells have been reported nearby up to alt of $400 \mathrm{ft}$. This particular sample coll. from shallow gully eroded in clay. Coll. 1916 by V. Stefansson, Canadian Arctic Expedition; subm. 1959. Comment: Lougheed Island has yielded no evidence of having been glaciated. Nonetheless, this datum indicates uplift of land, as does I (GSC)-21 (Craig and Fyles, 1960).

I(GSC)-27. Fort Selkirk, Yukon Territory

$>38,000$

Charred wood from steep right bank of Yukon River, $180 \mathrm{ft}$ above river, $3 \mathrm{mi}$ downstream from junction of Yukon and Pelly rivers $\left(62^{\circ} 4 \mathrm{l}^{\prime} \mathrm{N}\right.$ Lat, $137^{\circ} 27^{\prime} \mathrm{W}$ Long). Wood was contained in a 12 -in. lens of silt beneath $4 \mathrm{ft}$ of sand and gravel and beneath lava flows of the Selkirk volcanics. Coll. 1959 
by E. B. Owen; subm. 1959. Comment: dated materials belong to succession of gravel, sand, and silt that overlies till. Overlying lava flow bears glacial striae on its surface; hence deposits are inferred to be interstadial or interglacial.

\section{United States-Alaska}

The following results were obtained on a suite of samples from the Glacier Bay area, Alaska. Samples coll. and subm. by R. P. Goldthwait, Dept. of Geology, Ohio State Univ., Columbus. Ages ranging from $1400 \pm 90$ to 7075 \pm 250 , mainly on wood samples, have been determined. The following discussion, subm. by R. P. Goldthwait, outlines the significance of these dates.

The 21 samples from Muir, Adams, and Wachusett inlets in the NE reaches of Glacier Bay were dated to determine the time zones in a common local stratigraphy. All samples are logs, most of which were in place. In every situation (except I(OSU)-122 and I (OSU) -90) sorted gravels and sands lie directly on the wood, and indeed trees were killed by this burial and accompanying stream erosion. Some of these trees are rooted in the outwash which was building in the valley. Others (I(OSU) -83, 84, 88, 124, 126, and 163) grew in a forest mat and soil on bed rock up the valley wall. Obviously the outwash grew from bottom to top, from old to young. However, it was not expected that dates would be so remarkably consistent, falling on a straight altitude-time line (Goldthwait, 1960) from sealevel to $61 \mathrm{~m}$ alt. This implies growth of outwash at $1.4 \mathrm{~m}$ per century for over $4000 \mathrm{yr}$ in these several long inlet arms.

The only date inconsistent with this picture is that for I(OSU)-121 in sand right under the edge of Plateau Glacier. Being at sealevel it should come out about 6000 to $7000 \mathrm{yr}$ old, hut instead it is $2715 \pm 120 \mathrm{yr}$. A nearby log sample in place on bed rock at sealevel ( $(\mathrm{OSU})-163$ ) does give the expected order of magnitude. Possibly sample I(OSU)-121 was transported in sand and redeposited under ice; its root system was not seen.

Specimens I (OSU) -86, 123, 162, and 164, as well as earlier specimens Y-303, 304 and Y-301, 302 (Yale III) help to date lacustrine silt beds which occur commonly in the upper part of the gravels. Ponding was common to all three inlets ca. the same time, 4000 to $3000 \mathrm{yr}$ B.P.

Finally the whole area was invaded by the ice in a "Little Ice Age" advance. This is dated by $\mathrm{I}(\mathrm{OSL})-122$, one of many prostrate logs and stumps in place in imbedding till $(2735 \pm 160$ B.P.). Undoubtedly this time would be later at higher altitudes and further down the fiord inlets, but the only other relevant date is $\mathrm{I}(\mathrm{OSU})-90$, a stump in McBride Glacier moraine which is not positively in place.

I (OSU)-81. Nunatak Cove 1, Muir Inlet

$6335+220$

Picea (spruce) stump (id. by G. W. Burns) coll. at Muir Inlet, Nunatak Cove, in lower forest bed $0.5 \mathrm{mi} \mathrm{S}$ of entrance $\left(58^{\circ} 58^{\prime} \mathrm{N}\right.$ Lat, $136^{\circ} 07^{\prime} \mathrm{W}$ Long). Sample covered with $30 \mathrm{ft}$ gravel plus till, $88 \mathrm{ft}$ above tide.

I (OSU) -82. Nunatak Cove 2, Muir Inlet $\mathbf{5 2 3 5} \pm \mathbf{2 0 0}$

Picea (spruce) stump (id. by G. W. Burns) coll. at Muir Inlet, Nunatak Cove, in upper forest bed on $\mathrm{S}$ side of cove. $\left(58^{\circ} 58^{\prime} \mathrm{N}\right.$ Lat, $136^{\circ} 07^{\prime} \mathrm{W}$ Long). Sample lay under 5 to $10 \mathrm{ft}$ of gravel plus till, $57 \mathrm{ft}$ above tide. 


\section{I ( OSU) -83. W achusett Inlet 1}

$4215 \pm 200$

Tsuga (hemlock) stump (id. by G. W. Burns) coll. at Wachusett Inlet (off Muir Inlet) on N side by creek, near 1959 camp, $1 \mathrm{mi} \mathrm{NW}$ of island $\left(58^{\circ}\right.$ $57^{\prime} \mathrm{N}$ Lat, $136^{\circ} 15^{\prime} \mathrm{W}$ Long). Sample was in place on bed rock at alt $90 \mathrm{ft}$.

\section{I (OSU) -84. Westdahl Point, Muir Inlet}

$\mathbf{7 0 7 5} \pm \mathbf{2 5 0}$

Tsuga (hemlock) stump (id. by G. W. Burns) coll. at Muir Inlet on steep NE-facing shore of Westdahl Point, on W side of inlet $158^{\circ} 59^{\prime} \mathrm{N}$ Lat, $136^{\circ}$ $09^{\prime}$ W Long). Sample rooted on bedrock, lay under ca. $100 \mathrm{ft}$ of gravels at alt of $30 \mathrm{ft}$.

\section{I (OSU) -80. Goose Cove, Muir Inlet}

$4775 \pm 250$

Picea (spruce) $\log$ (id. by G. W. Burns) coll. at Muir Inlet, on E side at Goose Cove $\left(58^{\circ} 58^{\prime} \mathrm{N}\right.$ Lat, $136^{\circ} 06^{\prime} \mathrm{W}$ Long). Sample located under $20 \mathrm{ft}$ of gray gravel and possible till, at alt ca. $50 \mathrm{ft}$.

\section{I (OSU)-86. Geikie Inlet}

$3175 \pm 220$

Tsuga (hemlock) $\log$ (id. by G. W. Burns) coll. at Geikie Inlet in slope $\mathrm{N}$ of bay head $\left(58^{\circ} 37^{\prime} \mathrm{N}\right.$ Lat, $136^{\circ} 31^{\prime} \mathrm{W}$ Long). Sample located $100 \mathrm{ft}$ below top of terrace, in till-covered outwash gravel, $140 \mathrm{ft}$ above tide.

\section{I (OSU) -87. Charpentier Inlet}

$1825 \pm 150$

Tsuga (hemlock) log (id. by G. W. Burns) coll. $0.5 \mathrm{mi}$ upstream from Bulky Valley at head of Charpentier Inlet $\left(58^{\circ} 39^{\prime} \mathrm{N}\right.$ Lat, $136^{\circ} 27^{\prime} \mathrm{W}$ Long) . Sample located near hase of ca. $200 \mathrm{ft}$ of cross-bedded sands, ca. $300 \mathrm{ft}$ above sealevel.

I (OSU) -85. Adams Inlet 1

$1975 \pm 150$

Picea (spruce) stump (id. by G. W. Burns) coll. at Adams Inlet on E side of Muir Inlet ( $58^{\circ} 53^{\prime} \mathrm{N}$ Lat, $135^{\circ} 52^{\prime} \mathrm{W}$ Long). Sample excavated in SE corner of a low island, located in central part of Adams Inlet, overlain by $5 \mathrm{ft}$ of laminated clay and more silt and till, alt ca. $50 \mathrm{ft}$.

\section{I (OSU)-88. Forest Creek, Muir Inlet}

$2175 \pm 100$

Picea (spruce) stump (id. by G. W. Burns) coll. at Muir Inlet on middle of E side. where Forest Creek from Casement Glacier joins inlet $\left(58^{\circ} 57^{\prime} \mathrm{N}\right.$ Lat, $136^{\circ} 02^{\prime} \mathrm{W}$ Long). Sample located at least $200 \mathrm{ft}$ above tide, in forest mat on bed rock, covered by $3 \mathrm{ft}$ of recently-terraced gravel.

I (OSU)-90. McBride Glacier, Muir Inlet

$1975 \pm 200$

Taxus (?) stump (id. by G. W. Burns) coll. at upper E side of Muir Inlet $\left(59^{\circ} 01^{\prime} \mathrm{N}\right.$ Lat, $136^{\circ} 06^{\prime} \mathrm{W}$ Long). Sample in sharp N-lateral moraine of McBride Glacier at ca. $80 \mathrm{ft}$ above sealevel.

\section{I(OSU)-89. Queen Inlet}

$4755 \pm 180$

Picea (spruce) stump (id. by G. W. Burns) coll. at Queen Inlet, Carrol Glacier $\left(58^{\circ} 58^{\prime} \mathrm{N}\right.$ Lat, $136^{\circ} 00^{\prime} \mathrm{W}$ Long) on outwash apron $1 \mathrm{mi} \mathrm{NE}$ of tide flats. 
I(OSU)-91. Nunatak Cove 3, Muir Inlet

$7025 \pm 270$

Forest mat (duff), needles and twigs coll. at Muir Inlet, $0.5 \mathrm{mi} \mathrm{S}$ of Nunatak Cove $\left(58^{\circ} 58^{\prime}\right.$ N Lat, $136^{\circ} 07^{\prime}$ W Long), on mid-east side of inlet. Sample taken from lower forest bed $20 \mathrm{ft}$ above tide.

I(OSU)-124. Wachusett Inlet 2

$4750 \pm 160$

Wood (stump) coll. at Wachusett Inlet off Muir Inlet $\left(58^{\circ} 56^{\prime} \mathrm{N}\right.$ Lat, $136^{\circ} 14^{\prime} \mathrm{W}$ Long) on $\mathrm{N}$ side, $1 \mathrm{mi} \mathrm{NW}$ of island, in creek bend near camp. Stump was rooted at alt of $80 \mathrm{ft}$ in duff on lowest exposed bedrock, covered by gravel, forest beds, sand and till, totalling more than $30 \mathrm{ft}$.

I(OSU)-126. Wachusett Inlet 3

$3650 \pm 100$

Wood (stump) from Wachusett Inlet ( $58^{\circ} 56^{\prime} \mathrm{N}$ Lat, $136^{\circ} 14^{\prime} \mathrm{W}$ Long), $1 \mathrm{mi} \mathrm{NW}$ of island on $\mathrm{N}$ shore. Stump, rooted in forest mat on bed rock at $135 \mathrm{ft}$ alt, covered by sandy gravel ( $15 \mathrm{ft}$ or more) and till.

I(OSU)-125. Wachusett Inlet 4

$3900 \pm 100$

Wood (log) from Wachusett Inlet $\left(58^{\circ} 56^{\prime} \mathrm{N}\right.$ Lat, $136^{\circ} 14^{\prime} \mathrm{W}$ Long), $1 \mathrm{mi} \mathrm{NW}$ of island on $\mathrm{N}$ shore. Sample taken at alt of $113 \mathrm{ft}$ from sandy gravel at lower forest horizon. Horizon was overlain by sand, forest, gravel, and till, with coarse gravel beneath it.

\section{I(OSU)-123. Wachusett Inlet 5}

$3655 \pm 100$

Wood (log) from Wachusett Inlet $\mathrm{N}$ shore $\left(58^{\circ} 56^{\prime} \mathrm{N}\right.$ Lat. $136^{\circ} \mathrm{W}$ Long), $1 \mathrm{mi} \mathrm{NW}$ of island. Sample taken at alt of $152 \mathrm{ft}$ from upper forest layer or sand, overlain by gravel and till.

\section{I(OSU)-121. Plateau Glacier}

$2715 \pm 120$

Wood (stump) from Wachusett Inlet (58 $56^{\prime} \mathrm{N}$ Lat, $136^{\circ} 19^{\prime} \mathrm{W}$ Long) under edge of wasting Plateau Glacier on $\mathrm{N}$ shore, at head of bay. Wood was in place, projecting up through covering sand, ca. $5 \mathrm{ft}$ above mean sealevel.

\section{I (OSU)-122. Burroughs Glacier, Muir Inlet}

$2735 \pm 160$

Wood $(\log )$ from between Muir Inlet and Wachusett Inlet $\left(58^{\circ} 57^{\prime} \mathrm{N}\right.$ Lat, $136^{\circ} 11^{\prime} \mathrm{W}$ Long) on NW slope of hill, above wasting Burroughs Glacier. Wood half imbedded in surface till at alt of $658 \mathrm{ft}$.

I (OSU)-162. Adams Inlet 2

Wood from Adams Inlet (off Muir Inlet) $158^{\circ} 53^{\prime} \mathrm{N}$ Lat, $135^{\circ} \pm \mathbf{4 2 ^ { \prime }} \mathrm{W}$ Long), at head of bay on S shore. Sample was beneath ca. $150 \mathrm{ft}$ sands, fine gravel, and till, near top of $60 \mathrm{ft}$ of lacustrine clay.

I (OSU)-163. Wachusett Inlet 6

$6650+100$

Wood from Wachusett Inlet $\left(58^{\circ} 56^{\prime} \mathrm{N}\right.$ Lat, $136^{\circ} 18^{\prime}$ W Long) at head of bay on $\mathrm{N}$ side. Sample rooted in forest mat on weathered bedrock, covered by $5 \mathrm{ft}$ sandy gravel, ca. $3 \mathrm{ft}$ above mean tide and hence within reach of wave action. Burns locality 34; Goldthwait locality 13. Coll. 1956 by G. W. Burns, Ohio Wesleyan Univ. Delaware, Ohio.

I(OSU)-164. Adams Inlet 3

$3710 \pm 110$

Wood (log) from Adams Inlet (58 $53^{\prime} \mathrm{N}$ Lat, $135^{\circ} 42^{\prime} \mathrm{W}$ Long), at 
head of bay on $\mathrm{S}$ shore. Log located under at least $60 \mathrm{ft}$ lacustrine clay and $150 \mathrm{ft}$ sands, sandy gravel and till.

\section{E. Southern United States}

\section{I (MI) -27. Bellefontaine Marsh, Mississippi}

Gray-green mud from a zone 125 to $140 \mathrm{~cm}$ depth, in Bellefontaine Marsh, W of Pascagoula, Mississippi $\left(30^{\circ} 21^{\prime} \mathrm{N}\right.$ Lat, $88^{\circ} 41^{\prime} \mathrm{W}$ Long). This is a brackish coastal marsh, the sediments of which are slightly alkaline. Sampling area was $\mathrm{N}$ of long $\mathrm{N}$ to $\mathrm{S}$ loop of Graveline Bayou and Graveline Bay access to this area. Coll. and subm. 1957 by J. G. Erdman, Mellon Institute, Pittsburgh, Pennsylvania. Comment: sediment is recent deposit, well above eroded Pliocene interface. $\mathrm{C}^{14}$ age is consistent with ages of sediments in Mississippi Sound and on Gulf side of Horn Island (Erdman, 1961).

\section{I(MI)-112. Okefenokee Swamp, Georgia}

$4475 \pm 120$

Peaty sediment from Okefenokee Swamp, Georgia $\left(30^{\circ} 52^{\prime} \mathrm{N}\right.$ Lat, $82^{\circ}$

$19^{\prime} \mathrm{W}$ Long). Swamp is entirely fresh water and consists of marsh grasses and cypress, with "islands" on which pine and some oak are abundant. Sample taken at depth 115 to $130 \mathrm{~cm}$, in cypress-marsh area below roots of cypress tree measuring $11 \mathrm{ft}$ in circumference at shoulder height. Coll. 1957 and subm. 1959 by J. G. Erdman, Mellon Institute, Pittsburgh, Pennsylvania. Comment: $\mathrm{C}^{14}$ age is consistent with belief from tree-ring evidence that the tree, beneath the roots of which the sample was taken, is several thousand $\mathrm{yr}$ old. $\mathrm{C}^{14}$ age does not exceed probable age of the swamp.

\section{F. Eastern United States}

\section{I( MI) -9. Tamarack Swamp, Corry}

$2820 \pm 250$

Brown, peaty sediment, 115 to $130 \mathrm{~cm}$ depth, at Tamarack Swamp, near Corry, Pennsylvania $\left(42^{\circ} \mathrm{N}\right.$ Lat, $80^{\circ} \mathrm{W}$ Long). Tamarack Swamp is an acid, freshwater swamp or bog and represents a good example of a typical N swamp succession. Vegetation is largely tamarack and water-loving shrubs. Sphagnum moss is abundant. Coll. 1956 by J. G. Erdman; subm. 1957 by E. M. Marlett, Mellon Institute, Pittsburgh, Pennsylvania. Comment: radiocarbon age is consistent with the concept that bogs have developed in postglacial times.

I (USGS)-34. Borthwick Farm, Blackbird $\quad 15,100 \pm 600$

Slightly organic clay and siliceous silt coll. at Borthwick Farm near Blackbird, New Castle County, Delaware ( $39^{\circ} 21^{\prime} \mathrm{N}$ Lat, $75^{\circ} 40^{\prime} \mathrm{W}$ Long). Sample taken from depth 9.33 to $9.63 \mathrm{ft}$ in bottom of dark fill of undrained basin; a composite of 4 samples taken in the lower 4 in. of the hole, and part of a suite of 33 taken for pollen study. Sample from center of basin. Coll. 1957 by W. C. Rasmussen and O. J. Coskery, U. S. Geol. Survey, Newark, Delaware; subm. 1958 by W. C. Rasmussen. Comment: $\mathrm{C}^{14}$-age fits pollen succession. A sprucepine flora was determined for samples in lower $6 \mathrm{ft}$, followed by a mixed oakhardwood flora. Date would indicate this basin began to fill in Late Wisconsin time. 
II. ARCHAEOLOGIC SAMPLES

\section{A. United States}

I (UW )-79. Quimby, Iowa

$\mathbf{8 4 3 0} \pm \mathbf{5 2 0}$

Charcoal from Quimby site $\left(42^{\circ} 38^{\prime} \mathrm{N}\right.$ Lat, $95^{\circ} 36^{\prime} \mathrm{W}$ Long), $17 \mathrm{ft}$ below surface of bank of Little Sioux River, from hearths in which animals were believed to have been roasted. Extinct Bison occidentalis were found in association with side-notched points. Coll. 1958 by G. A. Agogino and W. D. Frankforter; subm. 1959 by G. A. Agogino, Univ. of Wyoming, Laramie.

I (UW)-141. Lindenmeier Site, Colorado

$10,780 \pm 135$

Charcoal from Folsom Level, Lindenmeier site, Ft. Collins, Colorado. Coll. 1959 by G. A. Agogino and C. V. Haynes, Jr.; subm. 1960 by G. A. Agogino, Univ. of Wyoming, Laramie. Comment: sample was first $\mathrm{C}^{14}$-date over 10,000 yr for Folsom. Estimated age of horizon from geologic evidence was ca. 10,000 yr (Libby, 1955).

I(TTC)-140. Lubbock Reservoir, Texas

$\mathbf{7 0} \pm \mathbf{7 0}$

Charred bone (Bison bison) from Lubbock Reservoir site, Lubbock, Texas ( $33^{\circ} 35^{\prime} \mathrm{N}$ Lat, $101^{\circ} 50^{\prime} \mathrm{W}$ Long). Lubbock Reservoir site is a wellknown Folsom locality (Libby, 1955), but this sample is from a comparatively recent occupation, ca. $12 \mathrm{ft}$ above the Folsom horizon. Bone was at base of small hearth that had been "sealed" after use, by a large rock. Coll. 1959 and subm. 1960 by F. E. Green, The Museum, Texas Technological College, Lubbock, Texas. Comment : hearth containing bone was in an occupation-level that should be of pre-pottery age, and should be several hundred yr older than indicated by radiocarbon date.

\section{B. Pacific Islands}

\section{Haatuatua Bay series}

Samples from site NHaa 1, Haatuatua Bay, Nuku Hiva, Marquesas $\left(9^{\circ}\right.$ 48' S Lat, $140^{\circ} 02^{\prime} \mathrm{W}$ Long). Coll. 1956-1958 and subm. 1958 by H. L. Shapiro and R. C. Suggs, The American Museum of Natural History, New York, N. Y. Site is an open dune fringing shoreline of Haatuatua Bay on Nuku Hiva, the main island of the $\mathrm{N}$ group in the Marquesas. Site had been used for burials and possibly ceremonial purposes and to one side lay house sites.

I (AMNH ) -39. Haatuatua Bay, bone

$1270 \pm 150$

Charred bone from burial area $4.5 \mathrm{ft}$ deep.

I (AMNH) -41. Haatuatua Bay, ash 1

$1090 \pm 180$

Ash from fire pit in habitation area $23 \mathrm{in.} \mathrm{deep.}$

I (AMNH) -43. Haatuatua Bay, charcoal $\quad 2080 \pm 150$ Charcoal in association with burials $4.5 \mathrm{ft}$ deep.

I (AMNH) - 48. Haatuatua Bay, ash 2

$1910 \pm 180$ 


\section{Bay Marquisien series}

Samples from series of sites in Bay Marquisien $\left(9^{\circ} 25^{\prime} \mathrm{S}\right.$ Lat, $140^{\circ} 02^{\prime}$ W Long) on W coast of Nuka Hiva. Coll. 1956 to 1958 and subm. 1958 by H. L. Shapiro and R. C. Suggs, The American Museum of Natural History, New York, N. Y.

I (AMNH) -44. Bay Marquisien, charcoal

Site NMB 1, charcoal from fire pit, 20.5 in. deep.

I (AMNH) -47. Bay Marquisien, leaves

$484 \pm 150$

Site $394 \mathrm{H}$, matted leaves from below fire bed at 5 to $10 \mathrm{in}$. below surface.

\section{MISCELLANEOUS SAMPLES}

I (RB) -46. Jenness Beach

$3640 \pm 230$

White pine stump from below tide at Jenness Beach, near Strows Point ( $42^{\circ} 59^{\prime} \mathrm{N}$ Lat, $70^{\circ} 46^{\prime} \mathrm{W}$ Long), on shore of Atlantic Ocean, Rye, New Hampshire. Mixed growth of pine and cedar in an area of two or more acres. Stumps are normally covered with sea sand and exposed only after a severe storm such as that of April 1958, and then only for a few weeks. Stumps are covered by 8 to $12 \mathrm{ft}$ of water at high tide. Coll. 1958 by A. B. and P. S. Drake; subm. 1958 by A. B. Drake, Rye Beach, New Hampshire.

Date lists:

\section{REFERENCES}

Lamont V Olson and Broecker, 1959

Yale III Barendsen, Deevey, and Gralenski, 1957

Yale V Stuiver, Deevey, and Gralenski, 1950

Barendsen, G. W., Deevey, E. S., and Gralenski, L. J., 1957, Yale natural radiocarbon measurements III: Science, v. 126, p. 908-919.

Craig, B. G., 1960, Surficial geology of north central district of Mackenzie, Northwest Territories: Canada Geol. Survey, Paper 60-18.

Craig, B. G., and Fyles, J. G., 1960, Pleistocene geology of Arctic Canada: Canada Geol. Survey, Paper 60-10.

Erdman, J. G., 1961, Some chemical aspects of petroleum genesis as related to the problem of source-bed recognition: Geochim. et Cosmochim. Acta, v. 22, p. 16-37.

Goldthwait, R. P., 1960, Dating the Little Ice Age in Glacier Bay, Alaska: Paper presented at XXI Internat. Geol. Cong., Copenhagen, August 1960; to be published in postcongress proceedings.

Lee, H. A., 1959a, Surficial geology of the southern district of Keewatin and the Keewatin ice divide, Northwest Territories: Canada Geol. Survey Bull. 5il.

1959b, Surficial geology, Grand Falls, New Brunswick: Canada Geol. Survey, Map 24-1959.

Map 24-1950, Late glacial and postglacial Hudson Bay sea episode: Science, v. 131,

Lee, H. A., Eade, K. E., and Heywood, W. W., 1960, Surficial geology, Sakami Lake, New Quebec: Canada Geol. Survey, Map 52-1959.

Libby, W. F., 1955, Radiocarbon dating, 2d ed.: Chicago, Univ. Chicago Press, ix, 175 p.

Olson, E. A., and Broecker, W. S., 1959, Lamont natural radiocarbon measurements V: Am. Jour. Sci. Radioc. Supp., v. 1, p. 1-28.

Stuiver, Minze, Deevey, E. S., and Gralenski, J. L., 1960, Yale natural radiocarbon measurements V: Am. Jour. Sci. Radioc. Supp., v. 2, p. 49-61.

Terasmae, J., and Fyles, J. G., 1959, Paleobotanical study of the glacial deposits from Vancouver Island, British Columbia: Canadian Jour. Botany, v. 37, p. 815-817.

Terasmae, J., and Hughes, O. L., 1960, Glacial retreat in the North Bay area, Ontario: Science, v. 131, p. 1444-1446.

Vries, Hessel de, 1958, Variation in concentration of radiocarbon with time and location on Earth: Koninkl. Nederslandse Akad. Wetensch. Proc., ser. B., v. 61, no. 2, p. 1-9. 